\title{
PROBLEMATIKA PENDIDIKAN PESANTREN DALAM MENINGKATKAN INSAN AKADEMIS BERKUALITAS DI ERA GLOBAL-MULTIKULTURAL
}

\author{
Buyung Surahman \\ buyungsurahman@iainbengkulu.ac.id
}

\begin{abstract}
Abstrak
Karya ilmiah ini menguraikan kendala yang dihadapi pendidikan pesantren dalam meningkatkan insan akademis berkualitas di era global-multikultural. Pesantren, Arus global bisa menimbulkan paradoks atau gejala kontra moralitas, dan begitu juga dengan pola kehidupan di barat, bahkan sangat mempengaruhi kerusakan akhlak, moral dan perilaku manusia. Dengan kondisi ini, pengaruhnya sangat besar pada kehidupan manusia baik sifatnya jasmaniah maupun rohaniah. Dengan demikian pendidikan pesantren dihadapkan berbagai tantangan dengan berkembangnya model-model pendidikan di era globalisasi yang dilaksanakan oleh anggota masyarakat, diantaranya problem sistem, problematika sumber daya manusia, pengembangan kurikulum. Oleh sebab itu, dalam upaya meningkatkan insan akademis berkualitas di era globalmultikultural, pesantren mengalami permasalahan untuk mengeksplorasi segala sumber daya yang dimilikinya, karena dipengaruhi oleh pendidikan pesantren terasa kurang concern terhadap persoalan, problematika sumber daya manusia, kuatnya pengaruh budaya barat dalam dominasi dan imperalisasi informasi, serta arus budaya globalisasi bisa menimbulkan paradoks atau gejala kontra moralitas. Dengan permasalahan ini, pesantren sudah saatnya mencurahkan segala daya, upaya dan kemampuanya untuk selalu berinovasi, menemukan sesuatu yang baru dapat membantu hidupnya menjadi lebih baik. Jika pesantren tidak menggali segala kemampuanya maka ia akan tertinggal oleh zaman yang selalu berkembang.
\end{abstract}

Kata Kunci: Problematika, Pendidikan, Pesantren

\begin{abstract}
This scientificwork outlines the obstacles facing pesantren education in improving quality academic people in the global-multicultural era. Pesantren, global currents can cause paradox or symptoms of counter-morality, and so does the pattern of life in the west, even greatly affect the moral decay, moral and human behavior. With this condition, the influence is very large on human life both physical and spiritual.
\end{abstract}


Thus pesantren education faced various challenges with the development of education models in the era of globalization implemented by members of the community, such as system problems, human resource problems, curriculum development. Therefore, in an effort to improve quality academic humanity in global-multicultural era, pesantren have problems to explore all the resources they have, because influenced by pesantren education is less concern to the problem, human resource problem, strong influence of western culture in domination and imperialisation of information, as well as the current culture of globalization can lead to paradox or symptoms of counter-morality. With this problem, pesantren is time to devote all the power, effort and ability to always innovate, finding something new can help his life for the better. If the pesantren does not dig all his skills then he will be left behind by the ever-evolving era.

Keyword: education, pesantren, spiritual

\section{A. Pendahuluan}

Pandangan klasik tentang pendidikan pada umumnya dikatakan sebagai pranata yang dapat menjalankan tiga fungsi sekaligus, yaitu Pertama: Menyiapkan generasi muda untuk memagang peranan tertentu dalam masyarakat di masa mendatang. Kedua: Mentransfer (memindahkan) pengetahuan sesuai peranan yang diharapkan, dan butir. Ketiga: Mentransfer nilai-nilai dalam rangka memelihara kebutuhan dan kesatuan masyarakat sebagai prasyarat bagi kelangsungan hidup (survive) masyarakat dan peradaban. ${ }^{1}$

Dari fungsi itu terlihat, ternyata pendidikan bukan hanya sebagai transfer knowledge (memindahkan pengetahuan) tetapi juga transfer of value (memindahkan nilai). Dalam perkembangan berikutnya, akesentuasi pengertian pendidikan itu sejalan dengan perkembangan tuntutan masyarakat. Dari sini lahir, misalnya dua fungsi suplementer yaitu melestarikan tata sosial dan tata nilai yang ada dalam masyarakat dan sekaligus agen pembaharuan.

Konsep pendidikan model Islam, tidak hanya meihat bahwa pendidikan itu sebagai upaya "mencerdaskan" semata (pendidikan intelek, kecerdasan) melaikan juga sebagai upaya dalam pembentukan kepribadian manusia. Istilah "Pendidikan" dalam konteks term "At-Tarbiyah, AtTa'lim, At-Ta'dib dan Ar-Riyadoh. Term-term tersebut tampaknya yang berkembang dan seiring dipergunakan oleh mayoritas ahli pendidikan Islam untuk menyebutkan istilah pendidikan adalah At-Tarbiyah. Karena mengingat cakupan yang dicerminkannya lebih luas dan bahkan istilah tarbiyah sekaligus mengimplikasikan makna dan maksud yang dicakup At-Ta'lim dan Tádib. Sehingga untuk menyebutkan pendidikan Islam menjadi tarbiyah Islamiyah. ${ }^{2}$

Pendidikan Islam jelas mempunyai peranan penting dalam peningkatan SDM. Dalam kerangka fungsi idealnya untuk peningkatan kualitas SDM, sistem pendidikan Islam haruslah senantiasa mengorientasikan diri untuk menjawab kebutuhan dan tantangan dalam masyarakat

1 Hasan Langgulung, Beberapa Pemikiran Tentang Pendidikan Islam, (Bandung: PT. Al-Ma'arif, 1980), hlm. 92

2 Muhaimin \& Abd. Mujib, Pemikiran Pendidikan Islam Kajian Filosofi Dari Kerangka Dasar Operasionalnya, (Bandung: Trigerda Karya, 1993), hlm. 127 
sebagai konsekuensi logis dari perubahan. Namun, pendidikan Islam hingga saat ini kelihatan masih terlambat merumuskan diri merespon perubahan dan kecenderungan perkembangan masyarakat sekarang dan masa akan datang. Sistem pendidikan Islam tetap lebih cenderung berorientasi ke masa silam ketimbang berorientasi ke masa depan, atau kurang bersifat future-orinted. ${ }^{3}$ Oleh karena itu, perlu adanya usaha inovasi dan pengembangan dalam sistem pendidikan Islam.

Pada saat sekarang ini, umat Islam mulai menyadari bahwa mereka tidak mungkin berkompetisi dengan kekuatan yang menantang kepada pihak Barat, Imperialisme modern dan misionaris Kristen, apabila mereka terus melanjutkan kegiatan dengan cara-cara tradisional dalam menegakkan Islam. Mereka mulai menyadari perlunya perubahan-perubahan, apakah ini dengan menggali mutiara-mutiara Islam dari masa lalu yang telah memberi kesanggupan kepada kawan-kawan mereka seagama pada abad tengah untuk mengatasi Barat dalam ilmu pengetahuan serta memperluas daerah pengaruh, atau dengan menggunakan metode-metode baru yang telah dibawa ke Indonesia oleh kekuasaan kolonial serta pihak misi Kristen.

Di Indonesia, inovasi pendidikan pesantren merupakan suatu hal yang sangat mendasar dan perlu dilaksanakan, agar dunia pendidikan kita dapat memenuhi tuntutan masyarakat dan pembangunan bangsa di segala bidang. Oleh karena itu, sistem pendidikan pesantren di Indonesia tak akan terlepas dengan mengeksplorasi segala sumber daya yang dimilikinya. Dengan cara mencurahkan segala daya dan kemampuanya untuk selalu berinovasi, menemukan sesuatu yang baru dapat membantu hidupnya menjadi lebih baik. Jika sistem pendidikan pesantren tidak menggali segala kemampuanya maka ia akan tertinggal bahkan tergerus oleh zaman yang selalu berkembang.

Kemajuan teknologi informasi sebagai fenomena yang bisa mempengaruhi pendidikan pesantren, apalagi dengan adanya banyak pendapat dan sikap dalam memaknai teknologi informasi, di antaranya ada yang bersikap pesimis dalam menyikapinya ini disebabkan oleh informasi global, karena cepatnya teknologi dan informasi media akan berakibat pada ketidaksiapan masyarakat dalam menghadapinya baik berupa sosial, budaya, agama, ekonomi, pendidikan dan lainnya, kemudian ada yang bersikap secara kritis positif tentang fenomena teknologi informasi dan pengaruhnya dalam pendidikan Islam. Yang lain ada juga yang bersikap bahwa teknologi informasi mempunyai pengaruh positif pada pendidikan Islam, jika peneliti ataupun ilmuwan kritis terhadap fenomena perkembangan teknologi informasi karena dianggap akan mengajak dan membawa ikatan persatuan dari orang-orang yang mempunyai perbedaan pola pikir dan sikap seperti agama, ras, suku, bahasa, agama dan lainya.

Arah pendidikan pesantren dalam masa ini mengarah pada pengembangan pandangan dunia dan substansi pendidikan pesantren agar lebih responsif terhadap kebutuhan tantangan zaman. Selain itu pembaharuan pesantren juga diarahkan untuk refungsionalisasi. Diharapkan pesantren tidak hanya berfungsi tradisional yakni transmisi dan transfer ilmu-ilmu Islam, pemeliharaan

3 Azyumardi Azra, Pendidikan Islam: Tradisi dan Modernisasi di Tengah Tantangan Milenium III. (Jakarta: Kencana Prenada Media Group. 2012), hlm. 31 
tradisi Islam dan reproduksi ulama, ${ }^{4}$ tapi juga menjadi pusat penyuluhan kesehatan, pusat pengembangan teknologi tepat guna bagi masyarakat pedesaan, pusat usaha penyelamatan dan pelestarian lingkungan hidup, dan lebih penting lagi menjadi pusat peningkatan insan akademis berkualitas. ${ }^{5}$

Dengan uraian di atas, bahwa pesantren semestinya merespon terhadap modernisasi pendidikan Islam di era era global dan multikultural yang mencakup: pertama, pembaharuan substansi atau umum dan vocational; kedua, pembaharuan metodologi seperti sistem klasikal; ketiga, pembaharuan kelembagaan, seperti kepemimpinan pesantren, diversifikasi lembaga pendidikan; keempat, pembaharuan fungsi dari yang semula hanya berfungsi kependidikan dikembangkan sehingga juga mencakup fungsi sosial-ekonomi.

Melihat kondisi pesantren dalam merespon era global dan multikultural guna mengarungi peningkatan insan akademis berkualitas maka memunculkan suatu ide untuk menggagas pesantren sebagai pusat pendidikan muslim di Indonesia. Namun tentunya mendapatkan kendala dalam perencanaan strategis pesantren yang berguna sebagai arah dalam rangka mewujudkan perubahan atau tujuan yang lebih baik dengan resiko kecil dan untuk mengurangi ketidakpastian masa depan.

\section{B. Konsepsi Pengembangan Insan Akademis Berkualitas}

Dalam Upaya Peningkatan Insan yang cerdas dan berkarakter adalah cara berpikir dan berperilaku yang menjadi ciri khas tiap individu untuk hidup dan bekerjasama, baik dalam lingkup keluarga, masyarakat, bangsa dan negara. Individu yang berkarakter baik adalah individu yang bisa membuat keputusan dan siap mempertanggungjawabkan tiap akibat dari keputusan yang ia buat. Dengan pendidikan karakter yang diterapkan secara sistematis dan berkelanjutan, seorang anak akan menjadi cerdas emosinya. Namun bagi sebagian keluarga, barangkali proses pendidikan generasi berkualitas yang sistematis di atas sangat sulit, terutama bagi sebagian orang tua yang terjebak pada rutinitas yang padat. Karena itu, seyogyanya pendidikan karakter juga perlu diberikan saat anak-anak masuk dalam lingkungan sekolah, terutama sejak play group dan taman kanak-kanak. Di sinilah peran guru, yang dalam filosofi Jawa disebut digugu lan ditiru, dipertaruhkan.

Investasi pengembangan sumber daya manusiaselalu berjangka panjang, yang mempersiapkan manusia terdidik yang memiliki ilmu pengetahuan dan mempunyai kualitas yang tinggi, yaitu manusia yang berkaliber nasional dan internasional. Adanya gejala pengangguran manusia terdidik dewasa ini perlu mendapatkan perhatian serius. Misalnya, perlu dilakukan peninjauan ulang terhadap isi dan arah kurikulum pendidikan yang tidak sejalan dengan kebutuhan pembangunan. Perlu pengembangan paradigma pendidikan yang memposisikan individu yang mandiri, pembelajar, dan mengupayakan pengembangan serta pemberdayaan potensi untuk menjadikan dirinya sebagai upaya peninjauan kurikulum harus dibarengi dengan perubahan

4 Nurcholis Madjid, Bilik-bilik Pesantren, (Jakarta: Dian Rakyat), hlm. xxiii

5 Diyah Yuli Sugiarti, Strategi Pengembangan Pondok Pesantren Dalam Membangun Peradaban Muslim di Indonesia, edukasi, Vol. 3, No. 1, Maret 2011:8 - 37, hlm. 12 
perilaku pendidik selama ini yang lebih menekankan adanya penindasan terhadap peserta didik.

Padahal pendidikan yang ideal dan dapat mengembangkan potensi diri agar mandiri adalah pendidikan yang mengedepankan reward dan apresiasi kepada peserta didik dari pada punishment dan penindasan yang justru mengerdilkan jiwa peserta didik, membuatnya tidak kreatif dan tidak mandiri. Ketahanan suatu masyarakat ditentukan oleh tiga unsur ialah sumber daya alamnya, sumber daya manusianya yang berkualitas, dan sumber daya kebudayaan dan kesejarahannya. ${ }^{6}$ Hanya anggota masyarakat yang berbudaya, yaitu yang mempunyai kebanggaan terhadap masyarakat dan budayanya, akan menjadi unsur sumber daya manusia yang produktif di dalam era globalisasi. Manusia yang tidak berbudaya akan tenggelam dalan arus globalisasi dan dia tidak mepunyai identitas. Globalisasi sangat mempengaruhi negara-negara berkembang, tidak terkecuali Indonesia yang berpenduduk mayoritas Muslim. Pengaruh yang demikian itu juga akan dialami warganya, sumber daya manusianya. Oleh karena itu kesiapan bangsa Indonesia menghadapi era globalisasi ialah peningkatan kualitas. Persoalan peningkatan seutuhnya sumber daya manusia, yaitu kualitas manusia dengan keseimbangan aspek material dan aspek spiritual/ nilai keagamaan.

Jelaslah bahwa manusia berkualitas hendaknya menampilkan ciri sebagai hamba Allah yang beriman, sehingga hanya kepada Allah ia bermunajah, serta memberikan manfaat bagi sesamanya. Sekirannya lebih dalam ditelusuri, kedua ciri utama itu kita dapatkan pada manusia taqwa, sehingga manusia berkualitas dapat pula diartikan sebagai manusia yang beriman dan bertaqwa, ${ }^{7}$ artinya manusia yang berperilaku tawakkal, pemaaf, sabar, muhsin, mau bersyukur, berusaha meningkatan kualitas amalnya dan mengajak manusia lain untuk beramal. Untuk itu, keutamaan manusia berpangkal pada adanya iman kepada Allah dan keimannya diwujudkan dalam perilaku yang memberi manfaat bagi masyarakat, berilmu pengetahuan, dan beramal saleh.

Dengan demikian, manusia berkualitas adalah insan yang cerdas komprehensif, yaitu cerdas spiritual, cerdas emosional, cerdas sosial, cerdas intelektual,dan cerdas kinestetis. Cerdas spiritual, yaitu beraktualisasi diri melalui olah hati/kalbu untuk menumbuhkan dan memperkuat keimanan,ketakwaan dan akhlak mulia termasuk budi pekerti luhur dan kepribadian unggul. Cerdas emosional, yaitu beraktualisasi diri melalui olah rasa untuk meningkatkan sensitivitas dan apresiativitas akan kehalusan dan keindahan seni dan budaya, serta kompetensi untuk mengekspresikannya. Cerdas intelektual, yaitu beraktualisasi diri melalui olah pikir untuk memperoleh kompetensi dan kemandirian dalam ilmu pengetahuan dan teknologi; aktualisasi insan intelektual yang kritis, kreatif, inovatif dan imajinatif. Cerdas kinestetik, yaitu beraktualisasi diri melalui olah raga untuk mewujudkan insan sehat, berdaya-tahan dan terampil, serta aktualisasi insan adiguna. Insan kompetitif, yaitu insan yang berkepribadian unggul dan gandrung akan keunggulan, bersemangat juang tinggi, mandiri, pantang menyerah, bersahabat

6 H.A.R. Tilaar, Membenahi Pendidikan Nasional, (Jakarta: PT Rineka Cipta, 2012), hlm. 60

7 M.D.Dahlan, Konsep Manusia Berkualitas Yang Dipersepsi Dari Al-Qur'an, AlHadits dan Qoul Ulama, Makalah Seminar Nasional Fakultas Syari'ah dan Fakultas Tarbiyah Universitas Islam Indonesia, Yogyakarta, tanggal 19 Maret 2009, hlm. 7 
dengan perubahan,inovatif dan menjadi agen perubahan dan menjadi rahmat bagi semesta alam.

Empat kapital yang menggambar ciri manusia berkualitas, sebagimana diuraikan Djamaludin Ancok ada empat kapital, yaitu kapital intelektual (intelect capital), kapital sosial (social capital), kapital lembut (soft capital), dan kapital spritual (spritual capital). ${ }^{8}$ Maka, karakteristik yang dikemukakan al-Qur'an, menurut hemat penulis menjadi tolak ukur kualitas manusia, karena karakteristik tersebut diturunkan dari konfigurasi nilai-nilai yang dikemukakan al-Qur'an yang hadir bersama dengan kelahiran manusia ke dunia, dan menjadi sifat penentu dalam pembentukan kepribadian manusia, yaitu kualitas iman, ilmu pengetahuan, kualitas amal saleh, dan kualitas sosial.

\section{Kualitas Iman}

Keimanan merupakan kebutuhan hidup manusia, menjadi pegangan keyaninan dan motor penggerak untuk perilaku dan amal manusia. Iman sebagai syarat utama dalam mencapai kesempurnaan atau insan utama, dan merupakan langkah awal untuk menuju keshalihan dan mewujudkan perilaku, amal saleh dan pengorbanan manusia bagi pengabdian kepada Allah, karena iman juga sangat terkait dengan amal saleh. Dalam keadaan beriman, manusia dapat memperlihatkan kualitas perilaku, kualitas amal salah, dan kualitas sosialnya yaitu ketulusan dalam kehidupan pribadi maupun kehidupan masyarakat luas. Manusia berkualitas akan berjuang melawan penindasan, tirani, dan tidak membiarkan kediktatoran atau tindakan sewenang-wenang. Djamaludin Ancok ${ }^{9}$, pada pembahasan kapital spritual, mengatakan bahwa "semakin tinggi iman dan taqwa seseorang semakin tinggi pula kepital intelektual, kapital sosial, dan kapital lembut". Manusia yang beriman hatinya akan dibimbing Allah, jiwanya menjadi tenang dalam melakukan aktivitas hidupnya, dalam QS. at-Taghaabun: 11, Allah berfirman: “... Siapa yang beriman kepada Allah, Allah akan memimpin hatinya". ${ }^{10}$

\section{Kualitas Intelektual}

Kualitas intelektual sudah menjadi potensi awal manusia, karena ketika manusia diciptakan, "Allah mengajarkan kepada Adam segala nama benda". ${ }^{11}$ Untuk itu, manusia sejak lahir telah memiliki potensi intelektual, kemudian potensi intelektual ini dikembangkan. Kualitas intelektual merupakan perangkat yang sangat diperlukan untuk mengolah alam ini. Rasulullah bersabda "barang siapa yang ingin memperoleh kebahagian dunia, dengan ilmu dan barang siapa yang ingin memperoleh kebahagian akhirat, dengan ilmu dan barang siapa yang ingin memperoleh kebahagian keduanya juga dengan ilmu".

Ilmu pengetahuan dibutuhkan manusia guna menopang kelangsungan peradabannya, karena manusia diamanatkan Allah untuk mengolah dan memberdayakan alam ini. Oleh karena itu, ilmu yang dimiliki manusia menghantarkan manusia ketingkat martabat yang lebih tinggi

8 Djamaludin Ancok, Membangun Kompotensi Manusia Dalam Milenium Ke Tiga, Psikologika, Jurnal Pemikiran dan Penelitian Psikologi, Fakultas Psikologi UII Yogyakarta 2008, hlm. 12

9 Ibid

10 QS. at-Taghaabun (64): 11

11 QS. al-Baqarah (2): 31 
bila dibandingkan dengan makhluk ciptaan Allah yang lain. Al-Qur'an, memberikan derajat yang tinggi bagi manusia yang memiliki ilmu pengetahuan, dan memberikan perbedaan yang jelas antara manusia yang memiliki ilmu pengetahuan dan yang tidak memiliki ilmu pengatahuan. Perbedaan antara manusia berimu dan tidak berimu dalam al-Qur'an, memberikan pejalaran bahwa segala kejadian yang berlangsung, senantiasa dikembalikan kepada orang-orang yang berilmu pengetahuan (ahlinya), bahkan martabat mereka itu disusulkan setingkat kemudian sesudah martabat pada nabi dalam mangkasyafkan hukum Allah Ta’ala.

Djamaludin Ancok mengatakan bahwa, kapital intelektual adalah perangkat yang diperlukan untuk menemukan peluang dan mengelola ancaman dalam kehidupan. Banyak pakar yang mengatakan bahwa kapital intelektual sangat besar peranannya di dalam menambah nilai suatu kegiatan. ${ }^{12}$ Untuk itu, Ilmu pengetahuan telah menjadikan manusia dengan berbagai keahlian (ahliha). Tiap keahlian menjadi unsur penyempurna dalam perakitan kehidupan sosial. Tiap aspek sosial yang tidak dikaji oleh bidang ilmunya yang sesuai akan menimbulkan usaha yang di luar kontrol nilai sosial, dan besar kemungkinan dapat mengakibatkan terjadinya ketidakharmonisan (kerusakan) di bumi. ${ }^{13}$ Oleh karena itu, menempatkan ahli dalam suatu bidang kehidupan tertentu menjadi jaminan keadilan bagi kehidupan kemanusiaan.

\section{Kualitas Amal Saleh}

Amal saleh adalah pembentukan kualitas manusia, sebab tiap kerja yang dilakukan setiap saat merupakan ukiran kearah terbentuk kepribadian manusia. Amal saleh sebagai pengejawantahan iman, maka suatu pekerjaan yang dilakukan harus memiliki orientasi nilai. Ini berarti sistem keimanan teraktualisasi melalui kerja amal saleh, karena kerja semacam ini memilik dimensi yang abadi. Al-Qur'an menyampaikan bahwa "manusia akan dikembalikan kekondisi yang paling rendah, kecuali manusia yang beriman dan mengerjakan amal salah". ${ }^{14}$ Amal saleh merupakan perbuatan yang bernilai bagi manusia, dan itu pula yang akan dilihat dalam cermin hidupnya.

Menurut Ahmad Muflih Saefuddin bahwa, "amal terwujud di kala mereka memiliki ilmu pengetahuan. Tanpa ilmu pengetahuan tidak terwujud perbuatan yang memiliki makna bagi kehidupan manusia. Amal tidak terwujud jika tidak ada sikap percaya dalam dirinya, karena keraguan tidak dapat mewujudkan perbuatan". ${ }^{15}$ Oleh karena itu, amal perbuatan yang bermakna bagi kehidupan manusia, baru dapat terwujud apabila sebelumnya ada iman dan ilmu pengetahuan. Karena dengan beriman memberikan kelapangan terhadap penderitaan, memberikan kelapangan dalam beramal. Dengan demikian Iman dapat membentuk kekuatan dalam diri manusia untuk dapat mengubah penderitaan menjadi kebahagiaan, memberikan semangat kerja. Selain itu, amal saleh juga terkaitan dengan kualitas ilmu, karena dengan berilmu manusia memiliki orientasi kesanggupan melakukan perbaikan dan melakukan sesuatu

12 Djamaludin Ancok, Membangun Kompotensi, hlm. 12

13 Ahmad Muflih Saefuddin, Kualitas Akademis Lulusan Tarbiyah, Makalah : Seminar Nasional dan Sarasehan Mahasiswa Tarbiyah, Prospek Tarbiyah dan Tantangannya, Pada tanggal, 22-23 Januari 2012, Senat Mahasiswa Fakultas Tarbiyah, UII, Yogyakarta, 2012, hlm. 6

14 QS. at-Tiin: 5-6,

15 Ahmad Muflih Saefuddin, Kualitas Akademis Lulusan Tarbiyah, hlm. 7 
perbuatan amal untuk kepentingan dan kemaslahatan manusia.

\section{Kualitas Sosial}

Manusia sebagai makhluk sosial berfungsi terhadap masyarakatnya, artinya memiliki kemampuan untuk melakukan hubungan dengan orang lain, karena manusia merupakan keluarga besar, yang berasal dari satu keturunan Adam dan Hawa. Selain itu, Allah menjadikan manusia dalam berbangsa-bangsa dan bersuku-suku, agar mereka saling interaksi untuk saling mengenal dan tolong menolong dalan berbuat kebaikan dan bertaqwa. Sifat sosial yang dimiliki manusia sesuai dengan fitrahnya, yaitu adanya kesedian untuk melakukan interaksi dengan sesamanya. Dalam al-Qur'an, bahwa manusia dalam melakukan aktivitas sosial sifat yang terbangun adalah saling tolong-menolong. "Tolong-menolong dalam kebaikan dan taqwa, dan dilarang tolong-menolong dalam berbuat maksiat, berbuat kejahatan". ${ }^{16}$

Maka, kualitas sosial sangat terkait dengan kualitas iman, ilmu, dan amal selah. Djamaludin Ancok, juga mengatakan bahwa intelektual Kapital baru akan tumbuh bila masing-masing orang berbagai wawasan. Untuk dapat berbagi wawasan orang harus membangun jaringan hubungan sosial dengan orang lainnya. ${ }^{17}$ Semakin luas pergaulan seseorang dan semakin luas jaringan hubungan sosial (social networking) semakin tinggi nilai seseorang. Dalam al-Qur'an, mamusia diciptakan dalam berbangsa-bangsa dan bersuku-suku agar saling kenal mengal, saling tolongmenolong. Dengan dasar ini, manusia membangun jaringan silahturrahmi antara sesamanya sesuai dengan fitrahnya. Karena dengan jaringan silaturrahmi akan memberikan kebaikan yaitu manusia dapat membangun ukhuwwah antar semamanya, dengan silahturrahim antar semasamanya tercipta atau terbuka peluang-peluang yang lain, apakah berupa pengalaman, pengetahuan, amal, dan memperkuat ikatan persaudaraan yang dibangun atas dasar iman untuk menuju muara taqwa. Maka, manusia sebagai makhluk sosial sangat membutuhkan jaringan sosial, untuk membangun persaudaraan yang abadi.

Beberapa uraian di atas, kecerdasan yang tinggi, akan mampu memanipulasi unsurunsur kondisi yang dihadapi untuk sukses mencapai tujuan. Kemampuan, yaitu karakteristik diri individu yang ditampilkan dalam bentuk perilaku untuk memenuhi kebutuhan/tuntutan tertentu. Manipulasi, yaitu perilaku aktif dan disengaja untuk melihat dan mengorganisasikan dalam membentuk hubungan antar unsur yang ada dalam suatu kondisi. Unsur-unsur, yaitu hasil pemilahan/pemisahan atas bagian-bagian dari suatu kesatuan tertentu. Tujuan,yaitu kondisi yang diharapkan terjadi melalui penampilan kemampuan dalam bentuk usaha. Sukses adalah kondisi yang unsur-unsurnya sesuai dengan kriteria yang diharapkan.

Dengan demikian, terwujudnya paradigma baru dalam pendidikan masa depan mengisyaratkan aktualisasi keunggulan kemampuan manusia sebagai generasi cerdas yang kini masih tersembunyi dalam dirinya. Dalam kaitan dengan pengembangan manusia ada dua pendekatan yang saling melengkapi, yaitu pengembangan sumber daya manusia dan pengembangan kemampuan manusia. Pengembangan sumber daya manusia atau Human

16 Qs. al-Maidah (4): 2

17 Djamaludin Ancok, Membangun Kompotensi, hlm. 13 
Resource Development (HRD), terutama terfokus pada keterampilan, sikap dan kemampuan produktif ketenagakerjaan sehingga diperlakukan manusia sebagai "sumber untuk dimanfaatkan" (yaitu sebagai obyek), dalam mencapai tujuan ekonomi, terutama dalam jangka waktu pendek. Pengembangan itu tidak terjadi dari dalam, melainkan "diatur dari atas" sesuai kepentingan lingkungannya. Seyogyanya pendidikan itu teralihkan fokusnya kepada perkembangan dan keterwujudan kemampuan manusia atau Human Capacity Development (HCD) sepanjang hayat yang berhak dan mampu memilih berbagai peran dalam meraih berbagai peluang partisipasi, sebagai anggota masyarakat, sebagai orang tua, atau sebagai pekerja dan konsumen, yaitu suatu perkembangan yang arah dan sasarannya terutama terjadi dari dalam, namun disulut untuk aktualisasinya.

Pendidikan sebagai Investasi SDM potensi sumber daya manusia tersebut harus dikelola dengan baik agar berkualitas sehingga menjadi bonus demografi. Oleh karena itu pada periode tersebut harus dijadikan sebagai periode investasi besar-besaran di bidang sumber daya manusia untuk membangkitkan generasi emas Indonesia. Investasi sumber daya manusia akan dapat diwujudkan melalui peran strategis pembangunan bidang pendidikan dalam mempersiapkan sumber daya manusia yang berkualitas. Pendidikan generasi emas berkarakter merupakan suatu investasi SDM (Human Capital Investment) sehingga mampu menciptakan iklim yang memungkinkan bagi setiap warga negara untuk turut andil atau berperan serta dalam penyelenggaraan negara dan pembangunan. Agar dapat memberikan kontribusi itu setiap warga negara harus mengembangkan dirinya agar menjadi produktif sehingga dapat lebih bernilai baik secara ekonomi dan non-ekonomi. Pendidikan generasi emas berkarakter merupakan sistem rekayasa sosial terbaik untuk meningkatkan kesejahteraan,mencerdaskan bangsa,serta meningkatkan harkat dan martabat sekaligus membangun peradaban yang unggul.

\section{Konsepsi Pendidikan Pesantren di Era Global-Multikultural}

Di era globalisasi saat ini, di mana semua bergerak dan berubah semakin cepat dan kompetitif. Semua bidang tak terkecuali pesantren mengalami pergeseran dan tantangan serius. Dampak selanjutnya dalam dunia global adalah menghasilkan dua tipikal sifat ekonomi yaitu yang menguasai ilmu pengetahuan dan teknologi akan menghegomoni dan bertindak sebagai produsen dan tipe satunya menjadi manusia yang cenderung menjadi konsumen. ${ }^{18}$ Agar mampu mengikuti sekaligus berada di garda depan perubahan global tersebut maka harus memiliki terobosan-terobosan progresif, di samping adanya teamwork yang solit dan profesional, sistem manajemen yang efektif, dan kader-kader andal pengisi dan penggerak masa depan yang dipersiapkan sedini mungkin. Sebagai upaya dalam menghadapi modernisasi (globalisasi) tersebut, maka muncullah gagasan pembaharuan yang dikenal dengan ekspansi sistem dan kelembagaan pendidikan modern Islam dari kaum reformis muslim atau modernis muslim. Mereka memunculkan dua bentuk kelembagaan pendidikan Islam modern yaitu pertama sekolah-sekolah umum diberi muatan pengajaran Islam, kedua madrasah-madrasah modern.

18 A. Suradi, Globalisasi Dan Respon Pendidikan Agama Islam Di Sekolah, Jurnal MUDARRISUNA, Volume 7, Nomor 2, July-Desember 2017, hlm. 247. 
Pengembangan pendidikan pesantren tetap berkembang sesuai dengan tuntutan dan kebutuhan masyarakat dan untuk menjaga kelangsungan hidup pesantren, pemerintah telah memberikan bimbingan dan bantuan. Arah perkembangan pesantren dititik beratkan pada:

1. Peningkatan tujuan institusional pondok pesantren dalam kerangka pendidikan nasional dan pengembangan potensinya sebagai lembaga sosial di pedesaaan.

2. Peningkatan kurikulum dengan metode pendidikan agar efesiensi dan efektivitas pengembangan pondok pesantren terarah.

3. Menggalakkan pendidikan ketrampilan di lingkungan pondok pesantren untuk mengembangkan potensi pondok pesantren dalam bidang prasarana sosial dan taraf hidup masyarakat.

4. Menyempurnakan bentuk pesantren dengn madrasah menurut keputusan bersama tiga menteri tentang peningkatan mutu pendidikan pada madrasah. ${ }^{19}$

Hal yang harus diperhatikan dalam pengembangan pendidikan pesantren di era global ini, yaitu:

1. Tetap menjaga agar citra pondok pesantren di mata masyarakat, sesuai dengan harapan masyarakat dan orangtua yang memasukkan anaknya ke pondok pesantren. Untuk itu lulusan pesantren hendaklah mempunyai nilai tambah dibanding lulusan pendidikan lainnya yang sederajat.

2. Pondok pesantren merupakan bagian dari sistem pendidikan nasional, oleh sebab itu hendaknya selalu mengikuti aturan dalam pendidikan nasional

3. Hendaknya pesantren selalu terbuka terhadap perkembangan dan temuan-temuan ilmiah dalam masyarakat, termasuk dunia pendidikan, sehingga pesantren tidak tenggelam dalam dunianya sendiri.

4. Pondok pesantren hendaknya bisa dijadikan sebagai pusat studi (laboratorium agama), yang dapat mengkaji perkembangan dalam masyarakat, untuk kepentingan bangsa dan agama. ${ }^{20}$

Dalam rangka meningkatkan insan akademis berkualitas, pesantren dituntut untuk dapat mengikuti derap kemajuan zaman, maka pondok pesantren dituntut mengembangkan system pendidikan, yaitu:

\section{Tujuan Pendidikan Pondok Pesantren}

Transformasi tujuan pendidikan pesantren yang perlu diperhatikan adalah bagaimana melahirkan ulama' tetapi ulama' dalam pengertian yang luas, ulama' yang menguasai ilmuilmu agama sekaligus memahami pengetahuan umum sehingga mereka tidak terisolasi dengan dunianya sendiri. ${ }^{21}$ Oleh karena itu pesantren diharapkan memperbaharui tujuan dalam rangka penyempurnaan untuk mengikuti tuntutan zaman. Karena sekarang ini orang tua memasukkan anakknya ke pesantren tidak hanya untuk mencari ilmu saja, tetapi juga untuk mencari ketrampilan atau ijasah. Oleh karena itu, sebagaimana tesis Azra yang dikutip Suradi, bahwa

19 Hasbullah, Sejarah Pendidikan Islam di Indonesia, (Jakarta: Raja Grafindo Persada, 2010), hlm. 158

20 Zulhimma, Dinamika Perkembangan Pondok Pesantren di Indonesia, Jurnal Darul 'Ilmi Vol. 01, No. 02 2013, hlm. 179

21 Mujammil Qomar, Pesantren dari Transformasi, hlm 6 
perubahan pendidikan Islam, termasuk pesantren dimulai dari sistem dan kelembagaannya yang didasarkan prinsip modern. ${ }^{22}$

Oleh karena itu pesantren diharapkan memperbaharui tujuan dalam rangka penyempurnaan untuk mengikuti tuntutan zaman. Karena sekarang ini orang tua memasukkan anakknya ke pesantren tidak hanya untuk mencari ilmu saja, tetapi juga untuk mencari keterampilan atau ijasah. Dengan hal ini, hal-hal yang berhubungan dengan masalah keduniaan (sekuler) tanpa tersisihkan sehingga santri cenderung berlaku sakral dan lebih menekankan perilaku yang idealistis-normatif.

\section{Kurikulum Pendidikan Pesantren}

Saylor, Alexander dan Lewis, sebagaimana Wina Sanjaya, pengertian jumlah mata pelajaran harus ditempuh oleh peserta didik, merupakan konsep kurikulum yang sampai saat ini banyak mewarnai teori-teori dan praktik pendidikan. ${ }^{23}$ Menurut Eisner dan Vallence bahwa, "five orientations to curriculum are the development of cognitive processes, curriculum as technology, self-actualization or curriculum as consummatory experience, social reconstruction relevance, and academic rationalism" ${ }^{24}$

Jadi usaha transformasi kurikulum di sini lebih terletak pada usaha untuk mengadakan reevaluasi (penelaahan ulang) dan reaktualisasi konsep-konsep yang termuat dalam kitab keislaman. Karena para ulama dahulu dalam memberikan legitimasi hukum belum tentu sama situasi dan kondisi sekarang ini.

Kembali kita lihat dari sudut pandang perubahan sosial bahwa maka transformasi kurikulum ini sebenarnya merupakan bagian yang tidak dapat dipisahkan dari perubahan sosial itu sendiri. Sebagaimana Abdul Rachman Shaleh, perubahan kurikulum sesungguhnya merupakan keniscayaan dari proses dinamika pendidikan, sebab kurikulum bukanlah entitas yang berdiri sendiri yang tidak memiliki keterkaitan dengan entitas-entitas lain. ${ }^{25}$ Kurikulum adalah subsistem dalam dunia pendidikan yang tidak dapat dipisahkan dari proses dinamika yang terjadi dalam masyarakat. Oleh karena itu, kurikulum harus mampu mempersiapkan peserta didik dalam menghadapi tantangan masa depan.

\section{Metode Pembelajaran Pesantren}

Pendidikan pesantren merupakan metamorfosis dari pendidikan Islam tradisional menuju sistem pendidikan modern. Akan tetapi tetap mempertahankan keutuhan nilai-nilai Islam. Dalam hal ini sebagaimana Hamdani Ihsan dan Fuad Ihsan, bahwa ada tiga aspek yang terkandung dalam tujuan pendidikan yang hendak direalisasikan melalui metode yang mengandung watak dan relevansi tersebut, yaitu:

22 Suradi, Pemikiran Modern dalam Islam, (Bengkulu: IAIN Bengkulu Press, 2015), hlm. 122

23 Wina Sanjaya, Kurikulum dan Pembelajaran., hlm. 4

24 Elliot W. Eisner and Elizabeth Vallance, Conflicting Conceptions of Curriculum, (Berkeley: Staford University, 1990), hlm. 5-12

25 Abdul Rachman Shaleh, Madrasah dan Pendidikan Anak Bangsa: Visi, Misi dan Aksi, (Jakarta: RajaGrafido Persada, 2004), hlm. 169. 
a. Membentuk anak didik menjadi hamba Allah yang mengabdi kepada-Nya semata.

b. Bernilai edukatif yang mengacu pada petunjuk Alquran.

c. Berkaitan dengan motivasi dan kedisiplinan sesuai ajaran Alquran yang disebut dengan pahala dan siksaan. ${ }^{26}$

Langkah transformatif yang dimaksudkan di sini adalah langkah-langkah yang tidak hanya sekedar merubah bentuk dari aslinya menjadi bentuk yang baru tapi lebih penting justru terletak pada nilai-nilai positif konstruktif dari perubahan itu yaitu dari model pengajaran yang tradisional (klasikal-formal) dengan tidak meninggalkan ciri khas pesantren dan dari model pembelajaran yang membelenggu santri menjadi emansipatoris.

\section{Sistem Manajemen Pondok Pesantren}

Keberhasilan dalam sebuah pesantren juga tidak terlepas dari penataan sistem manajerial yang bagus. Biasanya pola manajemen pendidikan pesantren cenderung dilakukan apa adanya secara insidental sehingga kurang memperhatikan tujuan-tujuannya yang telah disistematisasikan secara hirarkis. ${ }^{27}$

Melihat perkembangan yang terjadi sekarang ini, terutama ketika bersentuhan dengan budaya-budaya global pesantren harus mengadakan transformasi manajemen pendidikannya. Karena sekarang masyarakat belajar di pesantren tidak hanya untuk mempelajari dan mendalami ilmu agama saja, tetapi juga ingin mendapatkan ketrampilan dan ijazah. Pada akhirnya, menurut Nurcholis Madjid respon pesantren terhadap modernisasi pendidikan Islam mencakup: pertama, pembaharuan substansi atau umum dan vocational; kedua, pembaharuan metodologi seperti sistem klasikal; ketiga, pembaharuan kelembagaan, seperti kepemimpinan pesantren, diversifikasi lembaga pendidikan; keempat, pembaharuan fungsi dari yang semula hanya berfungsi kependidikan dikembangkan sehingga juga mencakup fungsi sosial-ekonomi. ${ }^{28}$

Dengan demikian, pendidikan pesantren di era globalisasi adalah pesantren yang bisa memodifikasi antara kebutuhan masyarakat dengan tujuan pesantren sebagai lembaga pembinaan dan pemberdayaan umat. Tentunya, untuk mewujudkan hal ini, pesantren harus bertolak pada paradigma yang digunakan dan melakukan pembaharuan terhadap kekurangan-kekurangannya. Menurut Ahmad Tafsir, dalam Islam ada tiga paradigma besar pengetahuan. Pertama, paradigma sains, pengetahuan yang diperoleh akal dan indera seperti fiqh; kedua, paradigma logis yaitu pengetahuan dengan objek yang abstrak seperti filsafat; dan ketiga, paradigma mistik yang diperoleh dengan rasa. ${ }^{29}$

Selama ini pondok pesantren hanya membekali santri paradigma yang pertama dan yang ketiga. Sementara paradigma yang kedua kurang tersentuh. Untuk itu, pondok pesantren masa kini idealnya harus memasukkan paradigma yang kedua, yaitu paradigma logis, agar semua pengetahuan dapat dibekalkan kepada seluruh peserta didik. ${ }^{30}$ Dengan demikian, pesantren

26 Hamdani Ihsan dan Fuad Ihsan, Filsafat Pendidikan Islam (FPI), (Banung: Pustaka Setia, 1998), hlm. 164.

27 Marzuki Wahid, et. al., Pesantren Masa Depan, hlm. 124

28 Nurcholis Madjid, Bilik-bilik Pesantren, hlm. 24

29 Ahmad Tafsir, Ilmu Pendidikan dalam Perspektif Islam, (Bandung: Rosda, 2008), hlm. 204

30 Muhammad Jamaluddin, Metamorfosis Pesantren Di Era Globalisasi, Jurnal KARSA, Vol. 20 No. 1 Tahun 
modern idealnya bersikap aktif terhadap perkembangan ilmu pengetahuan, menyuburkan daya saing, tetapi tetap mampu mempertahankan pembinaan moral yang selama ini dianggap prestasi besar pondok pesantren. Kalau konsep ini bisa dilakukan dengan baik, pesantren akan semakin tumbuh mengakar kuat dan kredibilitasnya semakinnaik di tengah-tengah masyarakat.

\section{Probelamatika Pendidikan Pesantren di Era Global-Multikultural}

\section{Problematika sistem}

Permasalahan yang menjadi penghambat pengembangan sistem pendidikan pesantren yang ditemui diantaranya, yaitu:

a. Adanya pertentangan antara Ulama Muda dan Ulama Tua yang pada akhirnya melahirkan istilah Kaum Muda dan Kaum Tua.

b. Dikotomi atau diskrit

Di dalam Islam padahal tidak pernah membedakan antara ilmu-ilmu agama dan ilmu umum (keduniaan), dan/atau tidak berpandangan dikotomis mengenai ilmu pengetahuan. Itu dapat menyebabkan kemunduran peradaban Islam serta keterbelakangan sains dan teknologi di dunia Islam. Hal ini terjadi bukan saja karena faktor dari luar tapi juga banyak dipengaruhi oleh faktor-faktor dari diri kalangan pesantren itu sendiri, yang kurang peduli terhadap kebebasan penalaran intelektual dan kurang menghargai kajian-kajian rasionalempiris atau semangat pengembangan ilmiah dan filosofis.

c. Pembenturan umat Islam dengan pendidikan dan kemajuan Barat memunculkan kaum intelektual baru (cendekiawan sekuler).

Beberapa kalangan berasumsi bahwa sebagian besar kaum intelektual baru adalah hasil pendidikan Barat yang terlatih berpikir secara Barat. Dalam proses pendidikannya, mereka mengalami brain washing (cuci otak) dari hal-hal yang berbau Islam, sehingga mereka menjadi teralienasi (terasing) dari ajaran-ajaran Islam dan muslim sendiri. Bahkan terjadi gap antara kaum intelektual baru (sekuler) dengan intelektual lama (ulama), dan ulama dikonotasikan sebagai kaum sarungan yang hanya mengerti soal-soal keagamaan dan buta masalah keduniawian.

Di samping itu, problematika pendidikan pesantren yang sangat kompleks sebagai faktor penghambat jalannya pembaharuan pendidikan Islam dalam menghadapi arus globalisasi ini, yaitu:

a. Pendidikan pesantren seringkali dikesankan sebagai pendidikan yang tradisional dan konservatif, hal ini wajar karena orang memandang bahwa kegiatan pendidikan Islam dihinggapi oleh lemahnya penggunaan metodologi pembelajaran yang cenderung tidak menarik perhatian dan memberdayakan.

b. Pendidikan pesantren terasa kurang concern terhadap persoalan bagaimana mengubah pengetahuan agama yang bersifat kognitif menjadi suatu "makna dan nilai" yang perlu di internalisasikan dalam diri seseorang lewat berbagai cara, media dan forum. 
c. Metodologi pengajaran pesantren berjalan secara konvensional-tradisional, yakni menitikberatkan pada aspek korespondensitekstual yang lebih menekankan yang sudah ada pada kemampuan anak didik untuk menghafal teks-teks keagamaan daripada isu-isu sosial keagamaan yang dihadapi pada era modern seperti kriminalitas, kesenjangan sosial dan lain lain.

d. Pengajaran agama yang bersandar pada bentuk metodologi yang bersifat statis indoktrinatif-doktriner. ${ }^{31}$

Sebagai implikasinya, pengembangan pendidikan pesantren dalam arti pendidikan agama tersebut bergantung pada kemauan, kemampuan, dan political-will dari pembinanya dan sekaligus pimpinan dari lembaga pendidikan tersebut, terutama dalam membangun hubungan kerjasama dengan mata pelajaran lainnya. Hubungan (relasi) antara pendidikan agama dengan beberapa mata pelajaran lainnya dapat bersifat horizontal-lateral (independent), lateral-sekuensial, atau bahkan vertical linier.

Pengertian ini menggaris bawahi pentingnya kerangka pemikiran yang dibangun dari fundamental doctrins dan fundamental values yang tertuang dan terkandung dalam Al-Qur'an dan As-Sunnah shahihah sebagai sumber pokok, kemudian mau menerima kontribusi dari para ahli serta mempertimbangkan konteks historisnya. Karena itu, nilai Ilahi/agama/wahyu di dudukkan sebagai sumber konsultasi yang bijak, sementara aspek-aspek kehidupan lainnya didudukkan sebagai nilai insani yang mempunyai relasi horizontal-lateral atau lateral-sekuensial, tetapi harus berhubungan vertical-linier dengan nilai ilahi/agama.

Melaluiupayasemacam itu makasistem pendidikan Islam diharapkan dapat mengintegrasikan nilai-nilai ilmu pengetahuan, nilai-nilai agama dan etik, serta mampu melahirkan manusiamanusia yang menguasai ilmu pengetahuan dan teknologi, memiliki kematangan professional, dan sekaligus hidup di dalam nilai-nilai agama.

\section{Problematika Sumber Daya Manusia}

Sumber daya manusia yang dimiliki oleh output pendidikan pesantren belum kapabel dan masih rendahnya mutu, maka diharapkan mutu lulusan di pesantren dapat menghasilkan sumber daya manusia yang dapat berdaya saing di era globaliasasi ini sehingga mempunyai nilai jual yang siap kerja agar tidak menjadi "budak" di negeri sendiri. Semua permasalahan yang memperlemah kondisi umat harus diselesaikan melalui upaya strategis dalam memperkuat sumber daya umat Islam dengan cara memperoleh pendidikan keterampilan mulai dari bahasa asing, komputer, internet, teknologi dan pemberian beasiswa untuk belajar ke dalam dan luar negeri sehingga menghasilkan sumber daya manusia yang berkualitas dan berdaya saing, hendaknya setiap individu harus memiliki landasan dan kemampuan yang meliputi perilaku, kerja keras disiplin, tanggung jawab yang dapat dipercaya dan sejenisnya dengan berpedoman pada ajaran al-Qur'an dan al-Hadit's. ${ }^{32}$

31 Moh. Wardi, Problematika Pendidikan Islam Dan Solusi Alternatifnya (Perspektif Ontologis, Epistemologis dan Aksiologis), Tadrîs Volume 8 Nomor 1 Juni 2013, hlm. 59

32 Komaruddin Hidayat, Agama Masa Depan: Perspektif Filsafat Perennial, (Jakarta: Paramadina, 1995), hlm. 114 
Konsep pendidikan Islam sangat mementingkan sumber daya manusia (SDM) yang berkualitas, sekaligus juga mementingkan kualitas kehidupan duniawi dan ukhrowi secara integral, sedangkan Noeng Muhadjir menyebutnya sebagai sosok manusia integral-integratif. ${ }^{33}$

Peningkatan sumber daya manusia yang handal dan kompeten dalam pendidikan pesantren adalah merupakan tanggung jawab dan kapasitas ulama dan masyarakat termasuklah orangtua yang seharusnya memperhatikan pembinaan dan pendidikan anak-anak sebagai generasi penerus, dan tidak membiarkan pertumbuhan anak berjalan tanpa bimbingan, atau diserahkan pada guru pesantren saja atau pembantu rumah tangga. Inilah kekeliruan yang banyak terjadi dalam realitas kehidupan kita.

\section{Pengembangan Kurikulum}

Setiap kegiatan pendidikan agama Islam seharusnya diorientasikan pada pencapaian kompetensi yang berhubungan dengan pengembangan kecerdasan emosional, sosial, intelektual, intelligence, terlebih lagi pada aspek spiritual maka dalam mencapai tujuan yang diharapkan maka diperlukan media yang relevan di antaranya yang berupa kurikulum.

Menurut Dedi Mulyasa, kurikulum dapat diartikan sebagai seperangkat rencana dan pengaturan mengenai tujuan, kompetensi dasar, materi standar dan hasil belajara serta yang digunakan sebagai pedoman penyelenggaraan kegiatan pembelajaran untuk mencapai kompetensi dasar dan tujuan pendidikan. ${ }^{34}$ Kurikulum adalah suatu program pendidikan yang direncanakan, di programkan, dan dirancang sedemikian rupa secara sistematis yang berisi bahan ajar serta pengalaman belajar sehingga dalam program pendidikan memiliki arah dan tujuan yang akan di capai dan dari hasil yang dicapai kita dapat merevisi ulang dan mengembangkan program pendidikan untuk memperoleh hasil yang lebih baik dari sebelumnya sehingga suatu kurikulum pembelajaran dapat dikatakan selalu berubah-ubah sesuai dengan kebutuhan dan perkembangan pendidikan.

Menurut Husain Haikal bahwa dalam bidang pendidikan, hanya sibuk bergulat dengan kurikulum atau mengganti nama sekolah, sementara mutu pendidikan makin merosot. Indonesia seakan-akan berlari di tempat sementara Negari Jiran makin berkembang serta bermutu dunia pendidikannya. Akibatnya, Indonesia makin kekurangan SDM yang bermutu dan kekurangan ini diisi orang asing sehingga mereka berjumlah sekitar 7000 orang dan menyarankan untuk bercermin pada kiprah berbagai perguruan tinggi di luar negeri. Namun juga, perlu bercermin pada dinamika Pondok Modern Darussalam Gontor, sebuah ponpes yang terus berkembang walau dimulai dengan pendidikan anak usia dini. Dengan tekad yang kuat dan terus melakukan berbagai terobosan, pondok mampu bertahan dan berkembang. "Salah satu sebabnya barangkali Pondok Modern Darussalam Gontor tidak pernah mengikuti jejak pengelolaan pendidikan Indonesia yang asyik dengan gonta-ganti kurikulum, sementara pihak luar melihatnya sebagai salah satu contoh proyek untuk meraih rupiah. Menariknya, Pondok Modern Darussalam

33 Noeng Muhadjir, "Sistem Penyelenggaraan Pendidikan Islam Dalam Persepektif Modern" Makalah Seminar Internasional Modernisasi Pendidikan Islam, Sistem Metodologi dan Materi di Pondok Modern Gontor, 31 Agustus 1996.

34 Dedi Mulyasa, Kurikulum Tingkat Satuan Pendidikan, (Bandung: Rosda, 2007), hlm.46. 
Gontor tetap bertahan dengan kurikulum yang dimilikinya dan tidak tertarik untuk bergantiganti yang melelahkan serta membingungkan semua pihak yang terlibat terutama para guru, siswa, dan orang tua. ${ }^{35}$

Reformasi kurikulum pendidikan agama Islam dalam menghadapi era globalisasi diharapkan adanya perubahan, perbaikan dan penataan kembali secara struktur menjadi lebih baik. Kaitannya dengan kurikulum pendidikan agama Islam, agar dapat direformasi kembali agar kurikulum pendidikan agama Islam sesuai dengan tujuan pendidikan agama Islam sehingga dapat menghadapi berbagai masalah-masalah yang terjadi sekarang ini khusunya dalam menghadapi era globalisasi sehingga dapat memainkan perannya secara dinamis dan proaktif.

\section{Pengaruh Budaya Barat}

Adanya kekuatan Barat dalam dominasi dan imperalisasi informasi, yang dapat menimbulkan pendidikan liberalisme dan neoliberal yang konsepnya adalah kompetisi dan persaingan. Hampir semua sekolah, taman kanak-kanak hingga perguruan tinggi, didasarkan ideologi kompetisi. Kompetisi bisa memberi manfaat, baik individual maupun sosial, tetapi dengan kondisi tertentu. Orang yang sudah kuat dan mapan dalam ekonomi, pendidikan dan modal tidak fair jika berkompetisi dengan mereka yang lemah. Ini bukan kompetisi yang sehat, tetapi bisa menjadi eksploitasi dan kontraproduktif.

Ketika ideologi kompetisi dijadikan basis pendidikan, pendidikan tidak akan peduli dengan nasib mereka yang kalah. Pendidikan tidak akan peduli dengan pertanyaan: akan dikemanakan mereka yang bodoh, tidak mampu dan miskin? Pertanyaan seperti ini tidak hanya relavan bagi kaum neoliberal, tetapi sudah jelas jawabannya: mereka akan menjadi pecundang, tersingkir dan jadi warga kelas dua di masyarakat. Ini adalah konsekuensi logis dari ideologi kompetisi.

Ada beberapa faktor munculnya kapitalisme pendidikan di Indonesia diantaranya adalah orientasi pendidikan bukanlah untuk mencerdaskan kehidupan bangsa atau membangun karakter bangsa menuju insan kamil, akan tetapi berorientasi pada pemenuhan ketrampilan dasar (life skill) untuk pemenuhan teknis perusahaan asing yang jelas pro Barat dan kapitalis. ${ }^{36}$ Tantangan yang dihadapi oleh dunia muslim di era globalisasi ada dua hal, yakni yang bersifat subyektif dan bersifat obyektif. ${ }^{37}$ Yang bersifat subyektif berasal dari perasaan terasing yang sedemikian mendalam terhadap kebudayaan sendiri, sebagai akibat dominasi budaya barat yang berlangsung sedemikian lama. Perasaan terasing ini nampak jelas dalam rasa rendah diri, dalam sikap agresif terhadap orang lain, dan dalam sukarnya mencari kesepakatan untuk bertindak. Sedangkan masalah obyektif disebabkan oleh banyaknya kaum elit berpendidikan barat yang berkuasa di Negara kita untuk menjalankan dan mengandalkan lembaga-lembaga budaya warisan barat.

35 http://www.uny.ac.id/berita/uny, AKADEMIKA, Vol. 20, No. 01 Januari - Juni 2015, diakses tanggal 29 Desember 2017, hlm. 184

36 Kebijakan Kementrian Pendidikan dan Kebudayaan Riatas perbandingan, lihat M Yunus Abu Bakar, Pengaruh Paham liberal dan Neoliberal terhadap Pendidikan Islam di Indonesia, hlm. 152

37 Syah Idris Ja'far, Ahmad Farid (ed), Perspektif Muslim Tentang Perubahan Sosial., Terjemahan, (Budiman: Bandung. 1988), hlm. 146 


\section{Arus Budaya Globalisasi}

Dalam konteks pendidikan Islam, arus global bisa menimbulkan paradoks atau gejala kontra moralitas, yakni pertentangan dua fisi moral secara diametral. ${ }^{38}$ Begitu juga dengan pola kehidupan di barat, tentunya nilai-nilai dan pandangan-pandangan hidup itu sangat erat hubungannya, bahkan sangat mempengaruhi Kerusakan akhlak, moral, adab, dan perilaku manusia. Namun di Barat dan Indonesia mengenai nilai-nilai dan pandangan hidup itu tidak sama, maka pancarannya dan pengalamannya dalam bentuk perilaku hidup pun menjadi tidak sama. Dalam ketidaksamaan itu berlangsung pula proses persaingan dan berlomba untuk mempengaruhi pola pikir dan perilaku hidup manusia penghuni bumi ini. Pengaruhnya sangat besar pada kehidupan manusia baik sifatnya jasmaniah maupun rohaniah (fisik, dan mental, materiil dan spiritual). ${ }^{39}$ Pendidikan pesantren di Indonesia dihadapkan berbagai tantangan dengan berkembangnya model-model pendidikan di era globalisasi yang dilaksanakan oleh anggota masyarakat. Mulai dari tingkat taman kanak-kanak sampai perguruan tinggi, pencarian yang ideal tentang studi Islam terus dilakukan, terutama untuk mewujudkan cita-cita pendidikan Islam.

Di era globalisasi sebuah lembaga pendidikan mesti memiliki kualifikasi tertentu yang bertaraf internasional. Sebagaimana diketahui, orientasi pendidikan Islam di Indonesia masih belum begitu jelas, terutama dalam menentukan pola, arah, dan capaian tertentu yang diinginkan, sehingga pendidikan Islam kita dapat diakui secara internasional. Tantangan pendidikan Islam yang sudah diharuskan memiliki kualifikasi internasional, tidak lepas dari pandangan tentang studi Islam, yang selama ini diperdebatkan antara studi Islam di Timur dan Barat. ${ }^{40}$

Secara garis besar terdapat dua bentuk pendekatan dalam kajian Islam di Barat; teologis dan sejarah agama-agama. Pendekatan kajian teologis, yang bersumber dari tradisi dalam kajian tentang Kristen di Eropa, menyodorkan pemahaman normatif mengenai agama-agama. Karena itu, kajian-kajian diukur dari kesesuaiannya dengan dan manfaatnya bagi keimanan. Tetapi dengan terjadinya marjinalisasi agama dalam masyarakat Eropa atau Barat pada umumnya, kajian teologis yang normatif ini semakin cenderung ditinggalkan para pengkaji agama-agama. ${ }^{41}$

Sedangkan pendekatan sejarah agama-agama berangkat dari pemahaman tentang fenomena historis dan empiris sebagai manifestasi dan pengalaman masyarakat-masyarakat agama. Penggambaran dan analisis dalam kajian bentuk kedua ini tidak atau kurang mempertimbangkan klaim-klaim keimanan dan kebenaran sebagaimana dihayati para pemeluk agama itu sendiri. Dan, sesuai dengan perkembangan keilmuwan di Barat yang sejak abad ke-19 semakin fenomenologis dan positivis, maka pendekatan sejarah agama ini menjadi paradigma dominan dalam kajiankajian agama, termasuk Islam di Barat. ${ }^{42}$

38 Sudarman Danim, Agenda Pembaharuan Sistem Pendidikan. (Yogyakarta: Pustaka Pelajar, 2003), hlm. 64

39 M. Solly Lubis, Umat Islam Dalam Globalisasi, (Jakarta: Gema Insani Press. 1997), h.35AKADEMIKA, Vol. 20, No. 01 Januari - Juni 2015186

40 Khamami Zada, "Orientasi Studi Islam di Indonesia Mengenal Pendidikan Kelas Internasional di Lingkungan PTAI", Istiqro: Jurnal Penelitian Direktorat Perguruan Tinggi Agama Islam, Dirjen Kelembagaan Agama Islam Departemen Agama RI, Vol, VI/No. O2/2003, (Jakarta: Departemen Agama Republik Indonesia, 2003), hlm.1.

41 Azyumardi Azra, Pendidikan Islam, Tradisi dan Modernisasi..., hlm. 229-230.

42 Ibid 
Studi Islam era globalisasi di Barat, yang berusaha keras menampilkan citra yang lebih adil dan penuh penghargaan terhadap Islam sebagai agama dan peradaban, dengan mengandalkan berbagai pendekatan dan metode yang lebih canggih dalam ilmu-ilmu sosial dan kemanusiaan, bahkan tidak jarang dipelopori oleh sarjan-sarjana Muslim sendiri. Ini nampaknya menarik banyak perhatian dari generasi baru pengkaji Islam negeri ini. Departemen Agama bahkan memberikan dorongan lebih besar kepada dosen-dosen IAIN untuk melanjutkan studi tingkat pascasarjana ke Barat, sambil juga tetap meneruskan tradisi pengiriman dosen-dosennya ke Timur Tengah dan negeri-negeri muslim lainnya seperti Turki dan Asia Selatan. ${ }^{43}$

Sementara di tempat lain, studi Islam di Timur Tengah dianggap hanya melakukan pendekatan normatif dan ideologis terhadap Islam. Kajian Islam di Timur merujuk dari penerimaan terhadap Islam sebagai agama wahyu dari Allah yang bersifat transenden. Islam tidaklah dijadikan semata-mata sebagai obyek studi ilmiah yang secara leluasa ditundukkan pada prinsip-prinsip yang berlaku di dunia keilmuwan, tetapi diposisikan secara mulia sesuai dengan kedudukannya sebagai doktrin yang kebenarannya dapat dipercaya, diyakini tanpa keraguan. Dengan demikian, sikap ilmiah yang terbentuk adalah komitmen dan penghargaan. Upaya studi ilmiah ditujukan untuk memperluas pemahaman, memperdalam keyakinan dan kebaikan bagi kepentingan umat.

\section{E. Penutup}

Pendidikan pesantren di era global-multikultural ini idealnya bersikap aktif terhadap perkembanganilmu pengetahuan, menyuburkan daya saing, tetapitetap mampu mempertahankan pembinaan moral yang selama ini dianggap prestasi besar pondok pesantren. Namun konsep ini mengalami problem dalam pengembangannya. Permasalahan yang menjadi penghambat pengembangan sistem pendidikan pesantren yang ditemui, yaitu adanya pertentangan antara ulama muda dan ulama tua yang pada akhirnya melahirkan istilah kaum muda dan kaum tua, dikotomi atau diskrit, serta pembenturan umat Islam dengan pendidikan dan kemajuan barat memunculkan kaum intelektual baru (cendekiawan sekuler).

Problematika pendidikan pesantren yang sangat kompleks sebagai faktor penghambat jalannya pembaharuan pendidikan Islam dalam menghadapi arus globalisasi ini, yaitu pertama, pendidikan pesantren terasa kurang concern terhadap persoalan bagaimana mengubah pengetahuan agama yang bersifat kognitif menjadi suatu "makna dan nilai" yang perlu di internalisasikan dalam diri seseorang lewat berbagai cara, media dan forum. Kedua, problematika sumber daya manusia yang dimiliki oleh output pendidikan pesantren belum kapabel dan masih rendahnya mutu. Ketiga, kuatnya pengaruh budaya barat dalam dominasi dan imperalisasi informasi, yang dapat menimbulkan pendidikan liberalisme dan neoliberal yang konsepnya adalah kompetisi dan persaingan. Keempat, arus budaya globalisasi bisa menimbulkan paradoks atau gejala kontra moralitas, yakni pertentangan dua fisi moral secara diametral.

43 Yusril Ihza Mahendra, Studi Islam di Timur dan Barat dan Pengaruhnya terhadap Pemikiran Islam Indonesia, dalam Jurnal Ulumul Qur'an No. 3 Vol. 5 Tahun 1994), h. 17.AKADEMIKA, Vol. 20, No. 01 Januari - Juni 2015 188 


\section{Bibliografi}

Ancok, Djamaludin. Membangun Kompotensi Manusia Dalam Milenium Ke Tiga, Psikologika, Jurnal Pemikiran dan Penelitian Psikologi, Fakultas Psikologi UII Yogyakarta 2008.

Azra, Azyumardi. Pendidikan Islam: Tradisi dan Modernisasi di Tengah Tantangan Milenium III. Jakarta: Kencana Prenada Media Group. 2012.

Dahlan, MD. Konsep Manusia Berkualitas Yang Dipersepsi Dari Al-Qur'an, AlHadits dan Qoul Ulama, Makalah Seminar Nasional Fakultas Syari'ah dan Fakultas Tarbiyah Universitas Islam Indonesia, Yogyakarta, tanggal 19 Maret 2009.

Danim, Sudarman. Agenda Pembaharuan Sistem Pendidikan. Yogyakarta: Pustaka Pelajar. 2003.

Eisner, Elliot W. and Elizabeth Vallance. Conflicting Conceptions of Curriculum. Berkeley: Staford University. 1990.

Hasbullah. Sejarah Pendidikan Islam di Indonesia. Jakarta: Raja Grafindo Persada. 2010.

Hidayat, Komaruddin. Agama Masa Depan: Perspektif Filsafat Perennial. Jakarta: Paramadina. 1995

Ihsan, Hamdani dan Fuad Ihsan. Filsafat Pendidikan Islam (FPI). Banung: Pustaka Setia. 1998. Jamaluddin, Muhammad. Metamorfosis Pesantren Di Era Globalisasi. Jurnal KARSA, Vol. 20 No. 1 Tahun 2012.

Langgulung, Hasan. Beberapa Pemikiran Tentang Pendidikan Islam. Bandung: PT. Al-Ma'arif. 1990.

Lubis, M. Solly. Umat Islam Dalam Globalisasi. Jakarta: Gema Insani Press. 1997.

Madjid, Nurcholis. Bilik-bilik Pesantren. Jakarta: Dian Rakyat.

Mahendra, Yusril Ihza. Studi Islam di Timur dan Barat dan Pengaruhnya terhadap Pemikiran Islam Indonesia, dalam Jurnal Ulumul Qur'an No. 3 Vol. 5 Tahun 1994, jurnal AKADEMIKA, Vol. 20, No. 01 Januari - Juni 2015.

Muhadjir, Noeng. "Sistem Penyelenggaraan Pendidikan Islam Dalam Persepektif Modern" Makalah Seminar Internasional Modernisasi Pendidikan Islam, Sistem Metodologi dan Materi di Pondok Modern Gontor, 31 Agustus 1996.

Muhaimin \& Abd. Mujib, Pemikiran Pendidikan Islam Kajian Filosofi Dari Kerangka Dasar Operasionalnya, (Bandung: Trigerda Karya, 2003.

Mulyasa, Dedi. Kurikulum Tingkat Satuan Pendidikan. Bandung: Rosda. 2007.

Saefuddin, Ahmad Muflih. Kualitas Akademis Lulusan Tarbiyah, Makalah: Seminar Nasional dan 
Sarasehan Mahasiswa Tarbiyah, Prospek Tarbiyah dan Tantangannya, Pada tanggal, 22-23 Januari 2012, Senat Mahasiswa Fakultas Tarbiyah, UII, Yogyakarta. 2012.

Shaleh, Abdul Rachman. Madrasah dan Pendidikan Anak Bangsa: Visi, Misi dan Aksi. Jakarta: RajaGrafido Persada. 2004.

Sugiarti, Diyah Yuli. Strategi Pengembangan Pondok Pesantren Dalam Membangun Peradaban Muslim di Indonesia, edukasi, Vol. 3, No. 1, Maret 2011.

Suradi, A. Globalisasi Dan Respon Pendidikan Agama Islam Di Sekolah. Jurnal MUDARRISUNA, Volume 7, Nomor 2, July-Desember 2017.

Pemikiran Modern dalam Islam. Bengkulu: IAIN Bengkulu Press. 2015.

Tafsir, Ahmad. Ilmu Pendidikan dalam Perspektif Islam. Bandung: Rosda. 2008.

Tilaar, H.A.R. Membenahi Pendidikan Nasional. Jakarta: PT Rineka Cipta. 2012.

Wardi, Moh. Problematika Pendidikan Islam Dan Solusi Alternatifnya. Perspektif Ontologis, Epistemologis dan Aksiologis, Tadrîs Volume 8 Nomor 1 Juni 2013.

Zada, Khamami. "Orientasi Studi Islam di Indonesia Mengenal Pendidikan Kelas Internasional di Lingkungan PTAI”, Istiqro: Jurnal Penelitian Direktorat Perguruan Tinggi Agama Islam, Dirjen Kelembagaan Agama Islam Departemen Agama RI, Vol, VI/No. O2/2003. Jakarta: Departemen Agama Republik Indonesia, 2003.

Zulhimma. Dinamika Perkembangan Pondok Pesantren di Indonesia. Jurnal Darul 'Ilmi Vol. 01, No. 022013. 